\title{
The Effect of Religiosity on Work Ethic on Educators
}

\author{
Pengaruh Religiusitas terhadap Etos Kerja pada Pendidik
}

\author{
Yanuar Putri Agustina ${ }^{1}$, Ugung Dwi Ario Wibowo ${ }^{2}$ \\ ${ }^{1,2}$ Universitas Muhammadiyah Purwokerto, Indonesia
}

\section{ARTICLE INFO}

\section{Article history:}

DOI:

10.30595/pssh.v2i.119

Submitted: July 12, 2021

Accepted: Aug 2, 2021

Published: Sept 24, 2021

Keywords:

Educators, religiosity, police, work ethic

\begin{abstract}
This study aimed to determine the effect of religiosity on the work ethic of the educator at the State Police School (SPN) of the Central Java Police. This research is a quantitative study with 57 educators at the State Police School (SPN) of the Central Java Police. The data collection method used in this study is to use a work ethic scale with a reliability of 0.955 , a religiosity scale with a reliability of 0.906 . The data analysis technique used in this study was a simple linear regression analysis technique to determine the effect of religiosity on the work ethic of the State Police School (SPN) educators of the Central Java Police. The results showed that the calculated $\mathrm{F}=0.942$ and significant value $=$ 0.000 ( $\mathrm{p}<0.05$ ), it can be concluded that the hypothesis is accepted, there is an influence of religiosity on the work ethic of the State Police School (SPN) educators of the Central Java Police. It is also known that the coefficient of determination is 0.369 , which indicates that the influence of the independent variable (religiosity) on the dependent variable (work ethic) provides an effective contribution of $36.9 \%$.
\end{abstract}

This work is licensed under a Creative Commons Attribution 4.0 International License.

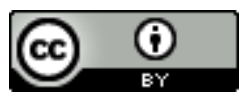

\section{Corresponding Author: \\ Yanuar Putri Agustina \\ Universitas Muhammadiyah Purwokerto, Indonesia \\ Email: yanuarputri88@gmail.com}

\section{INTRODUCTION}

The police agency is an important state institution, especially for the people of Indonesia. Apart from being law enforcers, other duties and responsibilities are protecting and serving the community. The police as a state institution and the Indonesian people must also be good role models in ethically obeying existing laws. Therefore, the police must have a high work ethic, including educators who educate prospective police officers to produce police responsible for their profession.

Realizing a police member responsible for his profession requires appropriate education, one of which is the Sekolah Polisi Negara (SPN) Polda Jawa Tengah to obtain knowledge for prospective members of the Indonesian National Police. Educators in police education are qualified education personnel and participate in the implementation of Police education, one of which is educators. Furthermore, educators in the Peraturan Kepala Kepolisian Negara Republik Indonesia Nomor 14 Tahun 2015 tentang Sistem Pendidikan Kepolisian Negara Republik Indonesia article 3 paragraph 3(a) are professionals in charge of planning, implementing the learning process, and assessing learning outcomes at Setukpa (Sekolah Pembentukan Perwira), Pusdik (Pusat Pendidikan), Sebasa (Sekolah Bahasa), Sepolwan (Sekolah Polisi Wanita), dan SPN (Sekolah Polisi Negara).

Recognizing the importance of improving the quality of human resources, Sekolah Polisi Negara (SPN) Polda Jawa Tengah continues to strive to realize through improving the work ethic of educators, which must be implemented in an integrated manner with the process of improving the quality of educators.

Educators are tasked with implementing and preparing teaching and training plans for prospective police members; therefore, educators at SPN must educate them seriously. It takes a high work spirit, serving the work to worship God Almighty. In other words, educators who work must have noble thoughts on their work or can also be referred to as work ethic. The work ethic of every human resource involved in an organization, especially the police, is very much needed. Because with a good work ethic, a good work culture will also be formed (Tangdigling et al., 2019). 
Sinamo (2020) defines work ethic as positive work behavior rooted in clear awareness and strong beliefs accompanied by a high commitment to a job. Comfort in association, increased discipline, reduced functional supervision from superiors, decreased absenteeism, and workers always wanted to give the best for the organization (Triguno in Permata et al., 2020). Work ethic is displayed in a person through work behavior. It is based on personal values and customs, a combination of beliefs and values of family, religion, and ethnicity (Petty \& Hill, 2005).

The professional work ethic of educators is essential because a good work ethic from an educator can set an example for prospective police officers to hold professional responsibilities. Sinamo (2020) said eight aspects of the professional work ethic: work is grace, work is a mandate, work is a calling, work is actualization, work is worship, work is art, work is an honor, and work is service. A preliminary study found that the Central Java Sekolah Polisi Negara (SPN) educators have an excellent work ethic with discipline indicators in carrying out their duties, are not late for class, and are creative in teaching in class responsible assertive. This proves that the work ethic of educators at the Central Java Sekolah Polisi Negara (SPN) fulfills eight aspects of the professional work ethic (Sinamo, 2020).

The results of previous studies prove that work ethic is influenced by several variables, including religiosity (Budi, 2019), human relations (Sugianti et al., 2020), conflict (Takwim, 2012), working environment conditions (Eriyanto et al., 2018), team building (Hadipranata \& Sudardjo, 1999), and motivation (Takwim, 2012). This research is focused on religiosity because, according to Budi (2019), if the level of religiosity is high, the work ethic will be increased. After all, religiosity is an incentive to work more productively and be more aware of the importance of the work being done. In addition, educators from the Sekolah Polisi Negara (SPN) of the Central Java Regional Police showed indications of a good level of religiosity, shown by always giving thanks when receiving sustenance in the form of services and materials, always worshiping on time according to their religion, and also respecting each other.

Therefore, this study aimed to measure the effect of religiosity on the work ethic of educators at the Sekolah Polisi Negara (SPN) Polda Central Java. According to Mansen (in Yudra et al., 2018), religiosity is influential in everyday human life; humans can avoid various harmful actions. Religiosity is closely related to the function of religion, so religious guidance will make individuals achieve inner peace so that negative feelings will disappear from their minds (Maryatmi, 2018).

Dister (in Khairunnisa, 2013) says that religiosity is the inner (personal) attitude of every human being before God which is known only to oneself, including the totality of the human person. In general, religion or religion has rules and obligations that must be obeyed and implemented by its adherents as a binding relationship with God. According to Ancok \& Suroso (2019), there are five dimensions of religiosity: the dimension of belief, the dimension of religious practice, the dimension of experience, the dimension of religious knowledge, and the dimension of practice or practice consequences. This research aims to identify the effect of religiosity on the work ethic of Sekolah Polisi Negara (SPN) Polda Jateng.

\section{THEORITICAL FRAMEWORK}

This research involves two research variables, namely, work ethic and religiosity. The explanation of these two variables can be seen in the next section.

\section{Work Ethic}

Sinamo (2020) defines work ethic as a set of positive work behaviors rooted in cooperation, and strong beliefs, accompanied by a commitment to a job. According to Chester (2012), the definition of work ethic is knowing what to do and what to do. A good work ethic is characterized by a positive attitude, reliability, professionalism, initiative, respect, integrity, and individual gratitude. Sennett (2019) mentions work ethic as selfdiscipline, hard work, and cooperation in work.

According to Lombardi \& Slonim (2014), work ethic is the appearance of a consistent and positive attitude towards all situations, manifesting a natural aura of being able and ready to perform any task that will contribute to the organization's good. On the other hand, many define that work ethic as a workaholic.

According to Karauwan \& Mintardjo (2015), work ethic is a positive attitude shown by a person when acting to achieve something optimally. Permata, Priyatama \& Satwika (2020) explain work ethic as the views and perspectives of individuals or groups towards their work and how individuals give whole meaning to their work.

Based on this description, it can be concluded that work ethic is a positive attitude in work done and shown by someone when acting with professionalism and initiative. There is individual gratitude in achieving something optimally.

\section{Religiosity}

Ancok \& Suroso (2019) define religiosity as a person's religious maturity, which encourages him to behave according to his level of obedience to religion or religion. According to Wahyudi \& Fauzi (2018), religiosity is a condition that enables individuals to act by the level of obedience to religion. Ita (2015) argues that religiosity is the maturity of the human person when faced with one stage of life or another. Chida, Steptoe \& Powell (2009) define religiosity as feelings, thoughts, experiences, and behaviors that arise from the search for the 'holy,' with social doctrines and practices and refer to experiences and beliefs. The term sacred refers to a divine being, divine object, ultimate reality, or ultimate truth perceived by the individual. Many different measures have been used to assess 
various aspects of religious or spiritual belief, practice, motivation, and commitment.

Nashori \& Mucharam (in Haryati, 2013) define religiosity as how strong the belief, the implementation of worship, and the rules and appreciation of the religion are adopted. According to Dachrud \& Yusra (2018), one's religiosity is manifested in ritual worship and activities related to the religion he adheres to and directs each individual to become a good person and accustomed to behaving according to the teachings of his religion.

Based on the description above, it can be concluded that religiosity is the religious behavior of someone who can understand theories, values and apply religious practices adopted in various aspects of life, including work.

\section{RESEARCH METHODOLOGY}

The variables in this research were religiosity and work ethic. At the same time, the research method uses a quantitative approach. The data in the field by the educators amounted to 57 educators, with 3 of them being nonMuslims consisting of 13 middle educators (gadik Madya), 19 young educators (gadik Muda), and 25 first educators (gadik Pertama). The participants who filled out the questionnaire in this study were 51 educators of Sekolah Polisi Negara (SPN) Polda Jawa Tengah. The data collection tool uses a religiosity scale consisting of 31 items based on the dimensions according to Ancok \& Suroso (2019), which is: dimensions of belief, dimensions of religious practice, dimensions of experience, dimensions of religious knowledge, and dimensions of practice or consequences and a work ethic scale consisting of The 35 items are based on eight aspects of the professional work ethic according to Sinamo (2020), which is: work is grace, work is a mandate, work is a calling, work is actualization, work is worship, work is art, work is an honor, and work is service. Based on statistical analysis, the scale shows high reliability, $\alpha=0.955$ (work ethic) and $\alpha=0.906$ (religiosity). Data analysis uses quantitative analysis with simple linear regression method, categorizes and makes percentages. Statistical analysis using the help of the SPSS statistical program.

\section{RESULTS AND DISCUSSION}

This research hypothesizes an influence of religiosity on the work ethic educators of Sekolah Polisi Negara (SPN) Polda Jawa Tengah to test whether the X variable affects $\mathrm{Y}$; the technique used is a simple linear regression technique. The significance test ( $\mathrm{F}$ test) on the simple linear regression technique was carried out to test whether the independent variable affected the dependent variable. F regression $>\mathrm{F}$ table (4.03) or if the significance value (p) of $\mathrm{F}<(0.05)$.

Table 1. Signification Test

\begin{tabular}{ccccccc}
\hline & Model & Sum of Squares & df & Mean Square & F & Sig. \\
\hline 1 & Regression & 6241.043 & 1 & 6241.043 & 38.019 & $.000^{\mathrm{b}}$ \\
\cline { 2 - 7 } & Residual & 9028.676 & 55 & 164.158 & & \\
\hline Total & 15269.719 & 56 & & & \\
\hline
\end{tabular}

a. Dependent Variable: Etos Kerja

b. Predictors: (Constant), Religiusitas

Based on table 1, the calculated $\mathrm{F}=38.019$ with a significant level of $0.000<0.05$, the regression model can state that there is an influence of the religiosity variable $(\mathrm{X})$ on the work ethic variable $(\mathrm{Y})$.

Table 2. Simple Regression Test

\begin{tabular}{lccccc}
\hline & \multicolumn{2}{c}{ Unstandardized Coefficients } & $\begin{array}{c}\text { Standardized } \\
\text { Coefficients }\end{array}$ & \multirow{2}{*}{$\mathrm{t}$} & Sig. \\
\cline { 2 - 4 } Model & $\mathrm{B}$ & Std. Error & Beta & & \\
\hline $1 \quad$ (Constant) & 27.794 & 21.035 & & 1.321 & .192 \\
\hline Religiusitas & .907 & .147 & .639 & 6.166 & .000 \\
\hline
\end{tabular}

a. Dependent Variable: Etos Kerja

Based on the significant value of the coefficient table, it is known that the constant (a) value is 27,794 , the religiosity value (b/regression coefficient) is 0.907 . The constant of 27,794 means that the consistent value of the work ethic variable is 27,794 . The $\mathrm{X}$ regression coefficient of 0.907 states that for every $1 \%$ addition to the value of religiosity, work ethic increases by 0.907 . The regression coefficient is positive, so it can be said that the direction of the influence of the variable $\mathrm{X}$ on $\mathrm{Y}$ is positive.

Based on the significance value: the coefficients table obtained a significance value of $0.000<0.05$, so it can be concluded that the religiosity variable $(\mathrm{X})$ is related to the work ethic variable $(\mathrm{Y})$. Based on the $\mathrm{t}$ value: it is known that the $\mathrm{t}$ count is $6,166>\mathrm{t}$ table 2.004 so that it can be hypothesized that there is an influence of the religiosity variable $(\mathrm{X})$ on the work ethic variable $(\mathrm{Y})$.

Based on statistical data analysis, the frequency distribution data for each score is obtained as follows:

Table 3. Frequency Distribution of Religiosity Score

\begin{tabular}{cccc}
\hline category & Frequency & Percent & Valid Percent \\
\hline Very low & 4 & 7.0 & 7.0 \\
\hline Low & 11 & 19.3 & 19.3
\end{tabular}

Proceedings homepage: https://conferenceproceedings.ump.ac.id/index.php/pssh/issue/view/7 


\begin{tabular}{cccc} 
Medium & 16 & 28.1 & 28.1 \\
\hline High & 26 & 45.6 & 45.6 \\
\hline Total & 57 & 100.0 & 100.0 \\
\hline
\end{tabular}

The table shows that four respondents (7.0\%) have very low religiosity, 11 respondents $(19,3 \%)$ have low religiosity, 16 respondents $(28.1 \%)$ have moderate religiosity, and 26 respondents $(45.6 \%)$ have high religiosity.

Table 4. Frequency Distribution of Work Ethic Score

\begin{tabular}{cccc}
\hline category & Frequency & Percent & Valid Percent \\
\hline Very low & 1 & 1.8 & 1.8 \\
\hline Low & 18 & 31.6 & 31.6 \\
\hline Medium & 12 & 21.1 & 21.1 \\
\hline High & 26 & 45.6 & 45.6 \\
\hline Total & 57 & 100.0 & 100.0
\end{tabular}

The table shows that one respondent (1.8\%) has a very low work ethic, 18 respondents $(31.6 \%)$ have a low work ethic, $12(21.1 \%)$ respondents have a medium work ethic, and 26 respondents $(45.6 \%)$ have a high work ethic.

This study was conducted to reveal the effect of religiosity on the work ethic of educators at the Central Java Police State Police School (SPN). Based on the results of the regression analysis obtained F count $(38,019)>$ F table $(4,01)$ with a p-value of $0.000<(0.05)$. So the hypothesis is proven that there is an influence of religiosity on the work ethic of the SPN Polda Jateng educators. So if the level of religiosity is high, the level of work ethic will be higher, and vice versa. If the level of religiosity is low, the level of work ethic will be below.

Work ethic is a unique set of personal behavior that considers work as a habit that is applied to work and thus becomes a character to achieve the best results and as a doctrine of goodness and strength that is believed by a person or group of people and implemented in work behavior (Fitriyani et al., 2019). Police who have a high work ethic is shown by their persistence in maintaining the values of the police profession, being able to uphold the quality of their work, providing the best service to the community, and maintaining self-respect in carrying out their work (Permata et al., 2020). Several factors can affect the work ethic of educators, one of which is religiosity. Rozikan (2019) says that religiosity is a religious feeling that lives in the heart.

The results showed that there was an influence of religiosity on the work ethic of educators. Ancok \& Suroso (2019) argue that individuals who have religious maturity or high religiosity will behave according to religious rules, including behavior at work, and fulfill aspects of religiosity that support the belief, religious practice, experience, religious knowledge, and practice. Educators who have religious maturity will be able to show professionalism and sincerity in their work to behave according to the demands of the job and demonstrate a good work ethic. Budi (2019) explains that religiosity has a positive and significant effect on work ethic and provides an effective contribution of $37 \%$.

Religiosity can also affect other variables. In research conducted by Adhim (2009), religiosity has a significant effect on work performance. In a study conducted by Tamzil (2015), it was found that religiosity and self-adjustment had a substantial impact on performance. Then in Amalia (2019), it was stated that religiosity affected hardiness. Najiyah (2017) mentions that religiosity has a positive and significant effect on work loyalty. This proves that religiosity affects work ethic and other variables such as performance, hardiness, and work commitment.

The results of data analysis obtained a coefficient of determination ( $\mathrm{R}$ square) of 0.409 , meaning that religiosity contributed $40.9 \%$ to work ethic.

\section{CONCLUSION}

Based on the analysis and discussion results, it can be concluded that the hypothesis of the $\mathrm{f}$ test and $\mathrm{t}$-test is accepted, meaning that there is a significant influence between religiosity on the work ethic of the educators of Sekolah Polisi Negara (SPN) Polda Jateng. So that the higher the work ethic of the educators Sekolah Polisi Negara (SPN) Polda Jateng, and vice versa if the work ethic of the educators is also higher.

\section{REFERENCES}

Abadiyah, R., \& Isnaini, N. (2017). Human Relation, Bornout Dan Self Efficacy Dengan Kinerja Perawat Di Rs Muhammadiyah Siti. Sncp, 1(1), 59-66.

Alwagfi, A. A., Aljawarneh, N. M., \& Alomari, K. A. (2019). Work Ethics And Social Responsibility: Actual And Aspiration. Journal Of Management Research, 12(1). Https://Doi.Org/10.5296/Jmr.V12i1.15794

Ancok, D., \& Suroso, F. N. (2019). Psikologi Islam: Solusi Islam Atas Problem Psikologi (Cetakan Vi). Pustaka Pelajar.

Arikunto, S. (2013). Prosedur Penelitian Suatu Pendekatan Praktek. Pt. Rineka Cipta.

Budi, I. S. (2019). Pengaruh Religiusitas Terhadap Etos Kerja Pedagang Banjar Di Pasar Sudimampir Banjarmasin. Jurnal Ekonomi Syariah Dan Hukum Ekonomi Syariah, 5(2).

Chester, E. (2012). Reviving Work Ethic. Greenleaf Book Group Press.

Chida, Y., Steptoe, A., \& Powell, L. H. (2009). Religiosity/Spirituality And Mortality: A Systematic Quantitative Review. Psychotherapy And Psychosomatics, 78(2), 81-90. Https://Doi.Org/10.1159/000190791 
Dachrud, M., \& Yusra, Y. (2018). Pendidikan Berbasis Islam Dan Multikultural Dalam Keluarga Sebagai Pembentuk Religiusitas Pada Anak. Potret Pemikiran, 22(2). Https://Doi.Org/10.30984/Pp.V22i2.782

Dodi, R., Yunus, M., \& Amri. (2013). Pengaruh Iklim Organisasi, Etos Kerja, Dan Disiplin Terhadap Kinerja Karyawan Serta Dampaknya Pada Kinerja Pt.Arun Ngl Lhokseumawe Aceh. 2(1), 98-107.

Eriyanto, A. W., Sunaryo, H., \& M, K. (2018). Pengaruh Human Relation,Kondisi Lingkungan Kerja Dan Gaya Kepemimpinan Terhadap Etos Kerja. E-Jurnal Riset Manajemen, 81-90. Www.Fe.Unisma.Ac.Id

Hadipranata, A. F., \& Sudardjo. (1999). Pengaruh Pembentukan Kelompok (Team Building) Terhadap Etos Kerja Dan Kontribusinya Bagi Produktivitas Kerja Insani. Jurnal Psikologi, 26(1), 18-28. Https://Journal.Ugm.Ac.Id/Jpsi/Article/View/6996

Haryati, T. D. (2013). Kematangan Emosi, Religiusitas Dan Perilaku Prososial Perawat Di Rumah Sakit. Persona:Jurnal Psikologi Indonesia, 2(2), 162-172. Https://Doi.Org/10.30996/Persona.V2i2.109

Huruma, L. S. (2015). Globalization, Religion, and Religiosity In Tanzania. International Journal Of Sociology And Anthropology, 7(6), 151-157. Https://Doi.Org/10.5897//jsa2014.0555

Peraturan Kepala Kepolisian Negara Republik Indonesia Nomor 14 Tahun 2015 Tentang Sistem Pendidikan Kepolisian Negara Republik Indonesia, (2015). Https://Doi.Org/10.1145/3132847.3132886

Ita, M. (2015). The Limitations Of Bernard Matolino's "Limited Communitarianism": Continuing The Conversations On Personhood In African Philosophy. In Filosofia Theoretica: Journal Of African Philosophy, Culture, and Religions (Vol. 4, Issue 2). Https://Doi.Org/Http://Dx.Doi.Org/10.4314/Ft.V4i2.8

J. Ali, A. (2015). Islamic Work Ethic In A Dynamic World. Religions: A Scholarly Journal, $2015(1), 11$. Https://Doi.Org/10.5339/Rels.2015.Work.11

Karauwan, R., \& Mintardjo, V. P. K. L. C. (2015). Etos Kerja, Disiplin Kerja, Dan Komitmen Organisasi Pengaruhnya Terhadap Kinerja Karyawan Di Dinas Pekerjaan Umum Minahasa Selatan. Jurnal Riset Ekonomi, Manajemen, Bisnis Dan Akuntansi, 3(3), 1196-1207. Https://Ejournal.Unsrat.Ac.Id/Index.Php/Emba/Article/View/10125/9711

Khairunnisa, A. (2013). Hubungan Religiusitas Dan Kontrol Diri Dengan Perilaku Seksual Pranikah Man 1 Samarinda. Psikoborneo, 1(3), 126-131. Http://E-Journals.Unmul.Ac.Id/Index.Php/Psikoneo/Article/Download/3322/2252

Lombardi, D. N., \& Slonim, A. D. (2014). Manual Of Healthcare Leadership: Essential Strategies And Administrative For Physician Leaders. Mcgraw-Hill Education.

Maryatmi, A. S. (2018). Well-Being On Elderly: The Role Of Predictor Of Family Social Support And Religiosity. Advanced Science Letters, 24(5), 3414-3417. Https://Doi.Org/10.1166/Asl.2018.11392

Mayasari, R. (2014). Religiusitas Islam Dan Kebahagiaan (Sebuah Telaah Dengan Perspektif Psikologi). Al-Munzir, $7(2)$.

Nashori, F. (1999). Hubungan Antara Religiusitas Dengan Kemandirian Pada Siswa Sekolah Menengah Umum. Psikologika, 8 .

Nur, S. (2013). Konflik, Stres Kerja Dan Kepuasan Kerja Pengaruhnya Terhadap Kinerja Pegawai Pada Universitas Khairun Ternate. Jurnal Emba, 1(3), 724-727. Https://Doi.Org/10.1109/Siu.2009.5136498

Octaviani, E. D., Rustam, A., \& Rohmatun. (2011). Hubungan Antara Religiusitas Dengan Kedisiplinan Pada Anggota Polri. 6(2), 58-67.

Peraturan Kepala Kepolisian Negara Republik Indonesia Nomor 14 Tahun 2011 Tentang Kode Etik Profesi Kepolisian Negara Republik Indonesia. (2011). Https://Doi.Org/10.1017/Cbo9781107415324.004

Peraturan Kepala Kepolisian Negara Republik Indonesia Nomor 4 Tahun 2010 Tentang Sistem Pendidikan Kepolisian Negara Republik Indonesia. (2010).

Permata, E., Priyatama, A. N., \& Satwika, P. A. (2020). Etos Kerja Pada Anggota Kepolisian Ditinjau Dari Persepsi Dukungan Organisasi Dan Dukungan Sosial Keluarga. Insan Jurnal Psikologi Dan Kesehatan Mental, $5(1), 61$. Https://Doi.Org/10.20473/Jpkm.V5i12020.61-70

Petty, G. C., \& Hill, R. B. (2005). Work Ethic Characteristics: Perceived Work Ethics Of Supervisors And Workers. Journal Of Industrial Teacher Education, 42(2), 5-20.

Rozikan, M. Z. (2019). Pengaruh Religiusitas Dan Tanggung Jawab Sosial Terhadap Etos Kerja Islami Pada Karyawan Lembaga Filantropi. Jurnal Pendidikan Islam, 20(2), 191-209. Http://Irep.Iium.Edu.My/44744/

Sennett, R. (2019). The Corrosion Of Character. In I (Vol. 53, Issue Technology).

Sinamo, J. (2020). 8 Etos Kerja Profesional (Edisi X). Grafika Mardi Yuana.

Sugianti, D. A., Purwanti, R. S., \& Basari, M. A. (2020). Pengaruh Human Relation Terhadap Etos Kerja Pegawai (Studi Pada Dinas Pekerjaan Umum, Penataan Ruang, Perumahan Dan Kawasan Permukiman). Business Management And Enterpreneurship Journal, 2, 26-38.

Sugiyono, P. D. (2013b). Metode Penelitian Kuantitatif Kualitatif Dan R\&D. Alfabeta, Cv.

Sururin. (2004). Ilmu Jiwa Agama. Grafindo Persada.

Takwim, R. I. I. M. (2012). Pengaruh Konflik Dan Motivasi Kerja Terhadap Etos Kerja Dan Implikasinya Pada Kinerja Karyawan. Jurnal Riset Managemen, 1(1), 84-95. Https://Doi.Org/10.17509/Image.V1i1.2324

Tangdigling, D. E., Nursyamsi, I., \& Yusuf, R. M. (2019). The Effect Of Situational Leadership And Work Ethics On Employee Effect Of Situational Leadership And Work Ethics On Employee Performance Through Organizational Climate As Intervening Variables At Gowa Agricultural Development Polytechnic. Hubs, 1(4), 43-50.

Wahyudi, A., \& Fauzi, A. (2018). Implementasi Konsep Religiusitas Dengan Perilaku Sosial Santri Di Desa Panguragan Kecamatan Panguragan Kabupaten Cirebon. Jurnal Edueksos, 7(2). 
ISBN: 978-602-6697-94-3

Yudiani, E. (2016). Etos Kerja Islami Dosen Fakultas Ushuluddin Dan Pemikiran Islam Uin Raden Fatah Palembang Ditinjau Dari Religiusitas. Psikis: Jurnal Psikologi Islami, 2(1), 1-15.

Yudra, F. O., Psikologi, F., \& Riau, U. I. (2018). Hubungan Antara Religiusitas Dengan Stres Kerja Pada Anggota Brimob Polda Riau. 12(1), 12-21.

Yusuf, A. M. (2017). Metode Penelitian Kuantitatif, Kualitatif, \& Penelitian Gabungan. 